\title{
Captain Macheath's Execution Lament in The Beggar's Opera
}

Stacey Jocoy

\begin{abstract}
On the eve of his execution, Captain Macheath in John Gay's The Beggar's Opera (1728) sings a lament or "Last Goodnight". Unlike the rest of the opera's musical numbers, Macheath's lament is a medley consisting of ten tunes. Placing them in close succession, Gay created a mini-narrative embedded within the larger story, forming a climactic picture of Macheath's mind - clearly the most musically dynamic moment of the opera. Daniel Heartz likens Macheath's "delirium" lament with the quodlibet or medley, popular on the contemporary French stage. While this speaks to the dark humor of the piece, an Italian musical genre, the solo cantata, had only recently been introduced to English audiences and may also account for the style and placement of Gay's work. Johann Christoph Pepusch, responsible for musical settings in The Beggar's Opera, had published his English Cantatas in 1710, and Henry Carey had published comic cantatas throughout the 1720s. Comparing continental traditions and formal analysis of Macheath's lament, this study considers the lament as a musical combination of the French comic and the dramatic Italian cantata traditions, in which the two continental genres melded with the English ballad to create a musical, sociopolitical tour de force, mocking British and Italian conventions simultaneously.
\end{abstract}

\section{Keywords}

ballad opera, execution songs, ballad medley, cultural resonance, lament, The Beggar's Opera, John Gay, Johann Christoph Pepusch 
"Why then, friend, this is a downright deep tragedy."

The Player (The Beggar's Opera, III.xvi)

John Gay's The Beggar's Opera (1728) is most commonly interpreted in light of its immediate sociocultural contexts. This study suggests that, in addition to the parody of Hanoverian political and financial instabilities, The Beggar's Opera should also be understood on a deeper historical, cultural level. This "deep play”, as Dianne Dugaw has termed it, is even deeper than its much-celebrated textual allusions when the continuing cultural resonances that Gay layered into the action through the vehicle of music are considered (DUGAW 2001). These themes and allusions in many instances resonate back several decades - even centuries in some instances - and served to enrich and complicate contemporary reception. Gay appears to have chosen his musical language, like his textual language and the inverted plot itself, to challenge normative perceptions of British identity. A dense microcosm of this agenda can be seen in the set of songs performed by Captain Macheath in the final prison scene of the play.

When discussing the tunes of The Beggar's Opera, many studies defer to earlier musically based ballad studies, such as those by William Chappell and Claude Simpson, or have dismissed the semiotic quality of the tunes altogether (CHAPPELL and MACFARREN 1859; SIMPSON 1966). In his seminal study of ballad tunes, Chappell mentioned the idea of complexes of tune meanings, but this idea has been largely ignored until relatively recently (recently MARSH 2004). A notable exception is the penetrating study by Dugaw, who clearly perceived the interrelation of ballad tunes and lyrics that would have been understandable to contemporary audiences (DUGAW 2001: 54). Such information is particularly important to the study of The Beggar's Opera, as the messages conveyed by the text, even in the midst of his satire, are altered by an investigation into the inherent meanings of the tunes, the layering of meanings between the tunes, and the related sets of lyrics. Though this is true for The Beggar's Opera as a whole, it is particularly important in considering the final lament sung by Macheath from the "condemned hold" in anticipation of his execution.

It is well understood that John Gay's Beggar's Opera is a highly complex work that evoked and parodied many aspects of early eighteenth-century culture. Much of Gay's ridicule was levelled at Hanoverian British society, which was deep in the throes of socioeconomic transition toward a largely mercantile culture. While this transition had been in effect since the period of the English Civil War, the recent crash of the South Sea Bubble in 1720 and the resultant economic instability had witnessed the strengthening of the Whig faction that brought Robert Walpole to even greater prominence as Britain's first prime minister. Even more interesting and complex are the concomitant social negotiations, wherein conservative or traditionalist figures registered their growing distrust of those who sought to define British life through increasingly financial relationships. Gay, along with his colleagues from the Scriblerian Club, Jonathan Swift and Alexander Pope, held closer to the traditionalist view and were generally not in favour of these Whiggish social and cultural transitions. Their aristocratic patron, Henry St John, Viscount Bolingbroke, went so far as to argue in print for a nostalgic return 
to Elizabethan values and social structures (ST JOHN 1749). While Gay's sophistication and urbane wit did not allow him to fully support Bolingbroke's plan, he did participate in a cultural resistance against what were understood by Tory and Patriot Whigs to be Walpolean innovations.

The Beggar's Opera has been understood to be part of that resistance in its parodic social commentary. Even in 1728 it was argued that "The Stage Turns all the World to Ridicule" on the title page to A Key to the Beggar's Opera. ${ }^{1}$ Contemporary commentators recognized that Gay, through the figure of the Beggar, was presenting a social mirror, albeit a fractured one that was meant to portray a world turned upside down; a world in which:

It is difficult to determine whether (in fashionable vices) the fine gentlemen imitate the gentlemen of the road, or the gentlemen of the road the fine gentlemen. (GAY 1969)

A modern study calls The Beggar's Opera "frivolously nihilistic", claiming that Gay's wry self-deprecation negates even the possibility of satire as there is no viable alternative "all the world is the same", as Macheath laments from his cell and Gay's mocking laughter is supposedly for himself as much as the rest of the world (HUME 1983: 260-269). Nevertheless, while there was much for Gay to lampoon in his immediate sociocultural contexts, his parody was not indiscriminate.

Gay chose to fashion his urban (or Newgate Prison) pastoral as a musical entertainment. The immediate learned appraisal of this initially, and through most of its history, was that the use of ballad tunes was a clever cultural riposte to the encroachment of foreign operatic styles. Gay, however, was well versed in ballad literature and traditions - he had written his own highly successful ballad, Sweet William's farewell to his Black-ey'd Susan (GAY 1720: II: 405-407) - and had reason beyond revelling in their nationalistic character to choose ballads as his music. It was Gay, not his composer Johann Christoph Pepusch, who chose the ballad tunes; Pepusch was mainly employed to offer suitable bass lines. ${ }^{2}$ Gay, like other ballad writers of the time, understood that ballad tunes, even without words, held semiotic significance for his audience. To analyze his text, assuming the music to be mere decoration, ignores half the message Gay was communicating to his knowing audience (NOBLE 1966). The words provide their levels of meaning, often communicating multiple or mixed messages, while the ballads that underlie them form a nexus of historical and historically consistent meanings, the understanding of which is crucial to a thorough and nuanced reading of each scene.

1 "Totus mundus agit Histrionem; / Anglice, / The Stage turns all the World to Ridicule" on the title page of A Key to the Beggar's Opera. In a Letter to Caleb Danvers, Esq.; appended to the end of Woman's Revenge: or, A Match in Newgate, by Peter Padwell of Padington, Esq. (alias Christopher Bullock), $3^{\text {rd }}$ ed. (London: George Faulkner and James Hoey, 1728), 49.

2 Many modern scholars have commented on Pepusch's relatively limited musical role, but even Charles Burney commented specifically on Pepusch's bass lines as his primary contribution; see (BARLOW 1990). 
In this study, I argue for the serious reappraisal of Macheath's final lament, which has been misrepresented in earlier scholarship. To establish the import of this lament, I first unpack the sociopolitical ramifications of its dramatic placement as a final speech. An understanding of the role of ballads, or "hangman's ballads", in the enormously popular arena of execution literature further reinforces contemporary cultural expectations surrounding Macheath's medley. This significantly colours the final piece in a new and much more serious light. Next, I consider Gay's use of the tunes themselves in Macheath's lament, listing them and discussing their individual relevance. Combined, the medley takes the listener through a programme of Macheath's moods, but further to this, tune associations in his medley emphasize his state in the society of the play: a rakish, tragicomic anti-hero, in an upside-down society where crime is considered positive, facing a death sentence, essentially for being a rake. The tunes thus form an additional layer of meaning that complicates, but also heightens the communication of Gay's traditionalist, patriotic message.

\title{
Sociopolitical Context: Final Speeches and Last Goodnights
}

\author{
"I die as brave as the best." \\ Captain Macheath (The Beggar's Opera, III.xiii)
}

Macheath's lament should be understood, as it doubtless was by eighteenth-century audiences, as part of the massive and popular genre of execution literature. It was a well-known custom that condemned criminals could, and often did, make a public account of their lives and actions, their motivations, and even regrets before their final hangman's dance. ${ }^{3}$ Tyburn itself became a region in London synonymous with both death - the three-sided "tree" could hang up to 24 people at a time and hangings were a regular monthly event - and free speech, as the condemned regularly spoke their final thoughts and prayers. ${ }^{4}$ This is the origin of the modern Speakers' Corner in Hyde Park. While versified versions of these speeches, also known popularly as hangman ballads or "last goodnights", had since Tudor times been popular morality literature (often laced with a healthy mix of scandal), the Civil War period had occasioned a great number of exciting and controversial political executions that had raised both interest and expectations on the part of English audiences. After the Restoration, fewer political prisoners were given the right to speak out against the government in their final words, but this void was filled with publications prepared for them by both sympathizers and mere profiteers (SHARPE 1985: 161-162). This literature, in the form of songs, poems, chapbooks, and final speeches was eagerly awaited and, like modern true crime texts, began to present more colourful versions to feed public interest. This

3 By the $17^{\text {th }}$ century the right to speak final words was considered to be the inalienable right of freeborn Englishmen; cf. (LINEBAUGH 1992: 91; MCKENZIE 2007: 34).

4 Regular hanging days were actually public holidays - audiences were encouraged to attend as such spectacles were thought to have a moralizing and chastening effect; see (SHARPE 1985; ROBERTS 2000). 
underscores the class politics and economic aspects of period criminalization. The spectacle of public executions, especially gallows songs and their popular consumption, highlighted fraught tensions embedded within the political relationship between state control over property, including human bodies, and civic resistance. The popularity of execution ballads placed these issues into sharp relief (LINEBAUGH 1992: 324-326).

Though many criminals met their deaths publicly, from the 1650s onward the figures that drew the largest crowds were often highwaymen. The reality of their crimes, as chronicled in chapbooks and collections of "last dying speeches", were often lessened in favour of a more romanticized portrayal. Claude Duval is the best known of the romanticized highwaymen, having a reported 200,000 witnesses at his hanging, many of whom were women. Duval was a Frenchman who cut a dashing figure across Restoration Britain, wooing the ladies, even purportedly dancing with them while holding up carriages at gunpoint. His final speech was supposedly found in his coat pocket and once it was made available in print it became an instant bestseller (WHITE 2004). Several of the earliest highwaymen that were captured mid-century claimed that they were responding to the "inequity of the times" - implying that a government controlled by regicides was in a poor position to judge the morality of others. Figures such as Captain Philip Stafford and James Hind claimed in their last speeches that in robbing primarily Parliamentary officials, they were serving their king - an equation that helped to further politicize and romanticize the Cavalier highwayman (MACKIE 2009: 77-84). Indeed the equation of loyalty with illegal activities was so pervasive that disenfranchised royalist aristocracy had revived the figure of Robin Hood in poetry and song as the iconic image of aristocracy turned outlaw against an unjust state prior to Gay's dashing highwayman (KNIGHT and HOOD 2003: 209).

Long after the Restoration, highwaymen remained both criminally active and, due to the literature surrounding their exploits, increasingly fascinating to contemporary audiences. Here execution literature regaled its readers with daring escapes, cunning disguises, and clever ploys - closer to thrilling yarns than contrite admissions of guilt. Collections of these accounts were gathered up into what were called "Newgate Calendars", which were avidly consumed. One of the first of these was The Tyburn Calendar, or Malefactors Bloody Register, published by G. Swindell (c1705), followed by Captain Alexander Smith's Compleat History of the Lives and Robberies of the Most Notorious Highwaymen (1719). Whether they were moralized at the end or not, audiences vicariously enjoyed the scandalous, rapacious activities of England's gentlemen outlaws. The dashing qualities of the highwayman melded with those of the rake (especially in figures like Duval) to such a degree that even learned men, such as James Boswell, sought to emulate them (MACKIE 2009: 86-87). This gallows literature, that heightened and glorified criminals for financial gain, was largely responsible for raising the figure of the common highwayman, and by extension Macheath, in popular esteem. 


\section{Macheath's Lament}

"There is nothing moves one so much as a great man in distress." Polly Peachum (The Beggar's Opera, III.xv)

Macheath's ballad medley, like those of other distraught or troubled characters before him, is characterized by its pervasive nostalgia. ${ }^{5}$ This musical nostalgia is a device that has several semiotic functions, the most important of which is to portray the character's asynchronicity with the world around them. Half of the tunes within his medley date back to the Civil War period, and at least two others date back to the Elizabethan period. Unlike earlier ballad medleys, however, this nostalgia does not merely indicate Macheath's distress or emotional imbalance but can also be understood to function on several sociopolitical levels. As was mentioned earlier in relation to Gay's Scriblerian contemporaries, their main aristocratic patron, Henry St John, Viscount Bolingbroke, was heavily invested in what has been described by his biographer, Isaac Kramnick, as a "politics of nostalgia" (KRAMNICK 1968: 77). His "primitive conservatism" held that the Elizabethan period was one of the last eras that exhibited true English spirit; he therefore advocated, through several literary means, a return to such values. Additionally, Macheath's imbalanced state in this piece, his melancholy, was a common social and literary trope of the Commonwealth and Restoration periods. That is, an individual's mental or emotional instability could be related back to the "sickness" or inversion of the times - a world turn'd upside down. Finally, the thematic political implications embedded within the tunes Gay chose to represent Macheath's lament were heavily associated with the turbulence of the Civil War period, and subsequently to the Glorious Revolution (1688). Such that, even if Gay's audience was not attune to all of the thematic resonances with the music itself, some of this information must have been conveyed, since many of the tunes still maintained popular currency.

Though Macheath's lamenting rant is not entirely coherent, much of what he says directly through Gay's lyrics is supported and enriched by the tunes that underlie his words. Taken together, as Gay's choice of musical form dictates, the tunes, along with their thematic connotations and new lyrics, form a conservative metaleptic discourse that recognizes current corruption but emphasizes traditional values. ${ }^{6}$ Though betrayal and Macheath's understandably concomitant feelings of anger about that betrayal are at the centre of this piece, his music goes beyond the text to argue for a traditionally rooted, patriotic worldview. Before one can fully appreciate the whole of Macheath's complaint, however, it is necessary to consider the component sections of the medley in more detail. Of all the hundreds of tunes available to help express his dying mock-hero's last thoughts before an ignominious death, Gay chose these ten tunes as some of the most popular and evocative of his day.

5 Shakespeare's Ophelia (Hamlet) and Edgar (King Lear) are some of the most famous mad characters from the Elizabethan period that were still recognized in the 1720s. For discussion of the nostalgia in Ophelia's songs, see (STERNFELD 1964; DUFFIN 2004: 407, 422).

6 For a discussion of metalepsis in the work of Gay, see (DUGAW 2001: 24). 
Table: Macheath's Final Medley (tunes 58-67)

\begin{tabular}{|c|c|c|c|}
\hline Air \# & Beggar's Opera Text & Original Text & Attrib. \\
\hline $\begin{array}{l}/ \\
\mathrm{LV} I I I^{*}\end{array}$ & $\begin{array}{l}\text { Oh cruel, cruel, cruel case! Must } \\
\text { I suffer this disgrace? }\end{array}$ & $\begin{array}{l}\text { Happy Groves: } \\
\text { Oh! Happy, happy Groves, Witness of our } \\
\text { tender loves; } \\
\text { Oh! Happy, happy shade, where first our } \\
\text { Vows were made. } \\
\text { Blushing, Sighing, Melting, Dying, Looks } \\
\text { would charm a Jove; } \\
\text { A Thousand pretty things she said and all } \\
\text { was Love: } \\
\text { But Corinna perjur'd proves, and forsakes the } \\
\text { shady Groves... }\end{array}$ & $\begin{array}{l}\text { John } \\
\text { Barrett }\end{array}$ \\
\hline $\begin{array}{l}2 / \\
\text { LIX }\end{array}$ & $\begin{array}{l}\text { Of all the friends in time of grief, } \\
\text { when threat'ning Death looks } \\
\text { grimmer, Not one so sure can } \\
\text { bring relief, as this best friend } \\
\text { a brimmer }\end{array}$ & $\begin{array}{l}\text { Sally in our Alley: } \\
\text { Of all the Girls that are so Smart, } \\
\text { there's none like pretty Sally; } \\
\text { She is the darling of my Heart, and She lives } \\
\text { in our Alley; } \\
\text { There is no Lady in the Land is half so Sweet } \\
\text { as Sally: } \\
\text { She is the darling of my Heart, and She lives } \\
\text { in our Alley... }\end{array}$ & $\begin{array}{l}\text { Henry } \\
\text { Carey }\end{array}$ \\
\hline $\begin{array}{l}/ \\
L X\end{array}$ & $\begin{array}{l}\text { Since I must swing, I scorn, } \\
\text { I scorn to wince or whine }\end{array}$ & $\begin{array}{l}\text { Britons, Strike Home: } \\
\text { Britons, Strike Home: Revenge your Coun- } \\
\text { try's Wrongs, } \\
\text { Fight and Record your selves in Druids' } \\
\text { Songs. }\end{array}$ & $\begin{array}{l}\text { Henry } \\
\text { Purcell }\end{array}$ \\
\hline $\begin{array}{l}4 / \\
L X I\end{array}$ & $\begin{array}{l}\text { But now again my spirits sink; } \text { I'll } \\
\text { raise them high with wine. }\end{array}$ & $\begin{array}{l}\text { Chevy Chase / Flying Fame } \\
\text { [Original text tells of a heroic figure who } \\
\text { continued to fight nobly in battle even after } \\
\text { his legs were cut off] }\end{array}$ & Anon \\
\hline $\begin{array}{l}5 / \\
L X I I\end{array}$ & $\begin{array}{l}\text { But valour the stronger grows, } \\
\text { The stronger liquor we're drink- } \\
\text { ing. And how can we feel our } \\
\text { woes, When we've lost the } \\
\text { trouble of thinking? }\end{array}$ & $\begin{array}{l}\text { Old Sir Simon the King / Ragged, Torn and } \\
\text { True: } \\
\text { [Texts set to this tune concern the concept } \\
\text { of loyalty; they are often Cavalier texts } \\
\text { about abuses they have endured in the } \\
\text { king's name] }\end{array}$ & Anon \\
\hline $\begin{array}{l}\text { 6/ } \\
\text { LXIII }\end{array}$ & $\begin{array}{l}\text { If thus a man can die much } \\
\text { bolder with brandy }\end{array}$ & $\begin{array}{l}\text { Joy to Great Caesar: } \\
\text { [Royalist and anti-Catholic political song } \\
\text { written by Thomas D'Urfey during the reign } \\
\text { of Charles II] }\end{array}$ & $\begin{array}{l}\text { Michael } \\
\text { Farinelli }\end{array}$ \\
\hline
\end{tabular}




\begin{tabular}{|c|c|c|c|}
\hline Air \# & Beggar's Opera Text & Original Text & Attrib. \\
\hline $\begin{array}{l}\text { 7/ } \\
\text { LXIV }\end{array}$ & $\begin{array}{l}\text { So I drink off this bumper and } \\
\text { now I can stand the test, And } \\
\text { my comrades shall see that I die } \\
\text { as brave as the best }\end{array}$ & $\begin{array}{l}\text { There was an Old Woman: } \\
\text { There was an old Woman liv'd under a Hill, } \\
\text { Sing Trolly lolly, lolly, lo; } \\
\text { She had good Beer and Ale for to sell, } \\
\text { Ho, ho, had she so... }\end{array}$ & Anon \\
\hline $\begin{array}{l}\text { 8/ } \\
\text { LXV }\end{array}$ & $\begin{array}{l}\text { But can I leave my pretty hus- } \\
\text { sies, without one tear, or tender } \\
\text { sigh? }\end{array}$ & $\begin{array}{l}\text { Did you ever hear of a gallant Sailor? / Ned } \\
\text { of the Hill: } \\
\text { But it grieves me far more } \\
\text { Than the loss of my store } \\
\text { That there's none } \\
\text { who would shield me from danger } \\
\text { So my fate it must be } \\
\text { To fare eastward o'er sea } \\
\text { And languish amid the stranger. }\end{array}$ & Anon \\
\hline $\begin{array}{l}\text { 9/ } \\
\text { LXVI }\end{array}$ & $\begin{array}{l}\text { Their eyes, their lips, their bus- } \\
\text { ses Recall my love } \\
\text { Ah, must I die? }\end{array}$ & $\begin{array}{l}\text { Why are mine eyes still Flowing?: } \\
\text { Why are my Eyes still flowing, Why do my } \\
\text { Heart thus trembling move? When do I sigh } \\
\text { when going } \\
\text { To see the darling Saint I love? }\end{array}$ & Anon \\
\hline $\begin{array}{l}10 / \\
\text { LXVII }\end{array}$ & $\begin{array}{l}\text { Since laws were made for ev'ry } \\
\text { degree, to curb vice in others as } \\
\text { well as me, I wonder we ha'nt } \\
\text { better company Upon Tyburn } \\
\text { tree! But gold from law can take } \\
\text { out the sting; And if rich men, } \\
\text { like us, were to swing, 'Twould } \\
\text { thin the land, such numbers to } \\
\text { string upon Tyburn tree! }\end{array}$ & $\begin{array}{l}\text { Greensleeves: } \\
\text { [Originally published in 1588, this tune was } \\
\text { associated primarily with texts about be- } \\
\text { trayal, usually of others betraying the state] }\end{array}$ & Anon \\
\hline
\end{tabular}

* The Arabic numerals are the number of the tune within the medley and the Roman numerals are Gay's original air numbers.

In a musical tour de force of ten connected tunes in immediate succession, Macheath communicates his shifting melancholy meditations. He begins with two pastoral tunes "Happy Groves" and "Sally in Our Alley" and then quickly shifts to tunes concerning the concept of loyalty, loss, and betrayal: "Britons Strike Home", "Chevy Chase", "Old Sir Simon the King", and "Joy to Great Caesar". As he progresses through pieces, he increases the strength of his alcoholic drinks, evoking the most popular ballad of 1728: "We are now arriv'd at the Boozing Ken" (LINEBAUGH 1992: 216). This performance states Macheath's social and behavioural code, positioning it textually and musically in an older Cavalier concept of British masculinity, which thereby challenged the newer ideological paradigm that represented his behaviour as criminal. Macheath's rakish qualities come to the fore in "There was an Old Woman" and "Did you ever hear of a Gallant Sailor". Here, 
Gay has isolated a relatively recent social and behavioural reevaluation: the rake had been a popular male dramatic persona in the Restoration period that had only recently lost favor on the stage due to the efforts of writers such as Colley Cibber, who were championing the newer sentimentalism movement (GOLLAPUDI 2006: 9-10). "Why are mine eyes still Flowing?" can be understood as Macheath's personal sadness, but this tune takes on important political overtones when it is placed next to the last tune: "Greensleeves". Ever about betrayal, "Greensleeves" for Macheath is a scathing rebuke of governmental hypocrisy. With this in mind, the earlier piece ("Why are mine eyes still Flowing?") is likely not simply about Macheath, but a melancholic, nostalgic remembrance of the regicide of King Charles I. ${ }^{7}$ This is not simply a question of proximity, but of the relational quality of the medley form which places pieces into a discourse. Macheath's focus here - his exploration of this issue in his final dying speech - is not simply maudlin reflection. Macheath's final lament is important musically, dramatically, and sociopolitically; its formal structure as a ballad medley and its relation to execution literature would have alerted contemporary audiences to its dramatic import, but the tunes underlying the lament form an additional body of material that, when combined with Gay's texts, convey Macheath's Cavalier manifesto.

Macheath's lament is redolent of older Cavalier values and ethics. He reminds his audience in the long-standing tradition of final speeches that he has remained true to a set of values and complimentary behaviours that were essential to the make-up of the Tory gentleman. ${ }^{8}$ His drinking, here in the depth of his confinement, is not futile escapism, but rather the resistant ebullience of loyalism; his overt sexuality - which has contributed greatly to his current predicament - is the prerogative of the rakish, Restoration gentlemen, not to mention the Cavalier highwayman; finally, like many of the royalist political martyrs of the seventeenth century, he understands and comments upon the "sickness of the times" - the world turned upside down, the Whiggish oligarchy ascendant. He cannot say, like King Charles I, that he does not recognize the authority of the system that condemns him; he recognizes it only too well and argues against its post- 1688 foundations as a corrupt government that began with and continued to abuse the traditional rights of its citizens. Using "Greensleeves", sometimes called a Tudor (or at least Elizabethan) "survivor" as a final musical subtext would also have reminded some audience members of the political nostalgia evinced by Tories and Patriot Whigs in such publications as The Craftsman. ${ }^{9}$ In the tradition, if not the form,

7 This tune first appeared in the song books of the 1650 s.

8 The changing and contested qualities of English masculinity in the period $c 1688-1750$ are integrally connected to concepts of national identity and ideology. On the level of individual self-fashioning, Mackie has persuasively argued that Restoration gentlemen constructed concepts of masculinity in equal measure from etiquette books and adventure stories of rakes, highwaymen, and pirates; this process legitimized certain negative behaviors based on their implicit social authority (MACKIE 2009: 31-32).

9 The Craftsman lasted nine to ten years as a successful Tory journal edited by Nicholas Amhurst (alias Caleb D'Anvers). Bolingbroke mainly contributed, $c 1727-1731$. For more information, see "6. The Craftsman and its Contributors, VIII. Historical and Political Writers, v IX. From Steele and Addison to Pope and Swift," in The Cambridge history of English and American literature: An Encyclopedia in eighteenth volumes. Available online at http://www.bartleby.com/219/0806.html. 
of the Italian operatic aria, this piece as a whole provides a picture of Macheath's mind at a moment of intense emotional turmoil. His text tells us what one would expect of a man in his situation, but the music enriches that text further, bringing the weight of both traditional and contemporary meanings to bear on his message of conservative patriotism.

\section{Final Thoughts}

"'Tis no matter how absurdly things are brought about." The Beggar (The Beggar's Opera, III.xvi)

The character of Captain Macheath clearly spoke to many aspects of the early modern British psyche. As the retrospective caricature of the Cavalier outlaw, Macheath argues for a re-examination of the process that has led from the general social approbation of his behaviour and lifestyle choices to its vilification - and more importantly on the immediate and practical level, to his imminent death sentence. His musical tirade is aimed at the capricious political powers of what he perceives to be an increasingly Whiggish society. His response is evocative of a kind of Tory rhetoric that spoke not only to traditions and the concept of a lost halcyon world, but also to an outdated concept of British social identity that, at least in the Restoration and Augustan periods, had still embraced his rakish qualities. His Cavalier persona also places him dangerously close to the spectre of Jacobitism, which, in 1728 would still have had its adherents; the merits of recognizing Macheath as a Jacobite are, however, outside of the scope of this study. Macheath speaks with the authority and freedom of the final dying speech - a genre that would have had appreciable contemporary impact. Expressing from the condemned hold what he may no longer be allowed to express on the public scaffold, Macheath recounts those things that are most important to him including finally the desire for a more egalitarian justice system.

Musically, the lament is notable for both its form and its texts. The lament is a dramatic musical climax and the only moment in the play where Gay chose to combine multiple pieces. These formal and affective considerations link Macheath's lament with other contemporary laments, which were most often found in the form of either a ballad medley or a solo cantata. This form would have carried its own contemporary associations as both an operatic allusion and, more importantly as an indication of Macheath's distressed state - akin to madness - in which he would have had an altered perception of life. In the inverted world of The Beggar's Opera, Macheath's rant, couched in musically mad signifiers, is actually sane. Macheath's main message, however, is carried in the texts and the ballad tunes that underlie his lyrics, which function as another layer of thematic information, or texts, meant to be understood in dialogic collusion with Gay's contrafacta. The associative power and historical relevance of the individual ballads are harnessed by the medley form, which melds and multiplies their significance. The ballad associations identified in the discussion 
of the specific tunes that comprise Macheath's lament, most notably the treachery communicated through "Greensleeves", confirm that Macheath's tirade was meant by Gay to be taken seriously.

Gay used the music as much as the text to convey his sociopolitical messages. The study of the semiotics of music recognizes that music is capable of conveying manifold meanings to different audiences. Studies such as those conducted by Philip Tagg of the semiotic markers within popular music identify the elements within music for televised entertainments that could also apply to the visual world of the broadside ballad (TAGG 2003: 94-96). Beyond such musically coded elements, however, ballad history appears to be an extreme example of semiotic tune associations that accreted over time, which allowed ballad tunes to bring more specific meanings to early modern English audiences. Gay was aware of many of the themes affiliated with the tunes he chose. Macheath's lament is one of the most obvious points in The Beggar's Opera where this interlayering of texts conveys a composite meaning. As such it may serve as a key to Gay's larger message, if such exists. ${ }^{10}$ Using the meanings discovered in Macheath's lament as a methodological key, a thorough mapping of the tunes and texts throughout the entire opera, sensitive to ordering and dramatic context may yet uncover further implications, especially if the music of Polly, the sequel to The Beggar's Opera, was also brought to bear.

Although Swift did not foresee the outcome of his whimsical suggestion to write a Newgate Pastoral, he could not have proposed the idea to a more suitable member of his Scriblerian cohorts. As a figure caught between the rarefied timbres of Twickenham and the hackneyed harmonies of Grub Street, Gay knew the popular songs of the street and how to use them, but he could also speak the language of the courtly poets and was able to sympathize with many of their worldviews. With this in mind, it is important to remember that after the lament is sung, the Beggar ultimately saves Macheath's life. By saving a figure that has been condemned by corrupt power structures - no matter how absurdly it is brought about - Gay ultimately sympathized with Macheath, reinforcing the reformed Tory/Patriot Whig message embedded within his lament. "All the world may be the same" as Macheath complained earlier in his disillusioned state, but his lament actively resists such nihilism in favor of change along reformed Tory precepts. It, and quite possibly Gay as well, thus make the final argument that with the necessary social ideological paradigm shift: "The wretch of today may be happy tomorrow" (III.xvii).

10 Such a larger message has been debated over the centuries; however, the idea that Gay is parodying the foibles of contemporary Whiggish society in favour of reinstituting a reformed Tory sensibility has been convincingly argued by (KRAMNICK 1968: 228-229). 


\section{Bibliography}

BARLOW, Jeremy (ed.). 1990. The Music of John Gay's The Beggar's Opera. Oxford: Oxford University Press, 1990.

Cambridge History. 1907-1921. 6. The Craftsman and its Contributors, VIII. Historical and Political Writers, v IX. From Steele and Addison to Pope and Swift. In The Cambridge History of English and American literature: An Encyclopedia in eighteenth volumes. Available online at http:// www.bartleby.com/219/0806.html.

DUFFIN, Ross W. Shakespeare's Songbook. New York/London: W. W. Norton, 2004.

DUGAW, Dianne. 2001. "Deep Play": John Gay and the Invention of Modernity. Newark: University of Delaware Press, 2001.

GAY, John. 1720. Poems on Several Occasions. London: Jacob Tonson and Bernard Lintot, 1720.

GAY, John. 1969. The Beggar's Opera. Edited by Edgar V. Roberts. Lincoln: University of Nebraska Press, 1969.

GOLLAPUDI, Aparna. 2006. Mending Manners: Reform Comedy and Culture 1696-1747. PhD dissertation. University of Connecticut, 2006.

HUME, Robert D. 1983. The Rakish Stage: Studies in English Drama, 1660-1800. Carbondale: Southern Illinois University Press, 1983.

CHAPPELL, William and Sir G. A. Macfarren. 1859. Popular music of the olden time; a collection of ancient songs, ballads, and dance tunes, illustrative of the national music of England. London: Cramer, Beale and Chappell, 1859.

KNIGHT, Stephen. 2003. Robin Hood: A Mythic Biography. Ithaca/London: Cornell University Press, 2003.

KRAMNICK, Isaac. 1968. Bolingbroke and his Circle, The Politics of Nostalgia in the Age of Walpole. Cambridge, MA: Harvard University Press, 1968.

LINEBAUGH, Peter. 1992. London Hanged: Crime and Civil Society in the Eighteenth Century. Cambridge, UK: Cambridge University Press, 1992.

MACKIE, Erin. 2009. Rakes, Highwaymen, and Pirates. Baltimore: John Hopkins University Press, 2009.

MARSH, Christopher. 2004. The sound of print in early modern England: the broadside ballad as song. In Julia Crick and Alexandra Walsham (eds.). The Uses of Script and Print, 1300-1700. Cambridge: Cambridge University Press, 2004.

MCKENZIE, Andrea. 2007. Tyburn's Martyrs Execution in England, 1675-1775. London: Continuum Books, 2007.

NOBLE, Yvonne. 1966. John Gay The Beggar's Opera: A Critical Edition. PhD dissertation. Yale University, 1966.

ROBERTS, John Michael. 2000. The Enigma of Free Speech: Speakers' Corner, The Geography of Governance and a Crisis of Rationality. Social and Legal Studies 9 (June 2000): 271-292.

SHARPE, J. A. 1985. 'Last Dying Speeches': Religion, Ideology and Public Execution in Seventeenth-Century England. Past and Present 107 (May 1985): 144-167.

SIMPSON, Claude M. 1966. The British Broadside Ballad and Its Music. New Brunswick, NJ: Rutgers University Press, 1966.

STERNFELD, F. W. 1964. Ophelia's Version of the Walsingham Song. Music and Letters 45 (April 1964): 108-113.

ST JOHN, Henry. 1749. Viscount Bolingbroke, Letters on the Spirit of Patriotism: on The Patriot King. Dublin: For J. Smith, 1749. 
TAGG, Philip. 2003. Ten Little Tunes Towards a musicology of the mass media. New York: The Mass Media Music Scholars' Press, 2003.

"Totus mundus agit Histrionem; / Anglice, / The Stage turns all the World to Ridicule" on the title page of A Key to the Beggar's Opera. In Letter to Caleb Danvers, Esq.; appended to the end of Woman's Revenge: or, A Match in Newgate, by Peter Padwell of Padington, Esq. (alias Christopher Bullock), 3rd ed. London: George Faulkner and James Hoey, 1728: 49.

WHITE, Barbara. 2008. Duval, Claude (d1670). In Oxford Dictionary of National Biography. Oxford University Press, 2004; online edition, Jan 2008. Available online at http://www.oxforddnb. com/view/article/8333. 


\section{Dr Stacey Jocoy}

School of Music, Texas Tech University,

$18^{\text {th }}$ and Boston Avenue Box 42033,

Lubbock TX 79409-2033, USA

stacey.jocoy@ttu.edu

Stacey Jocoy is associate professor of musicology at Texas Tech University. Her work in the early modern period focuses on intersections of music, performance, politics, and gender, interrogating the roles of music as cultural politics. Her work has been supported by fellowships from the Folger Shakespeare Library, the Huntington Library, the Andrew Clarke Library (UCLA), and the Newberry Library and appears in the Journal of Seventeenth-Century Music, Eighteenth Century Studies, and collections including Lords of Wine and Oile: Community and Conviviality in the Poetry of Robert Herrick (OUP) and Kingship and Madness on the Early Modern Stage (Routledge). 